\title{
Influence of Ultrasound Impact in the Process of the Stacking Cycle, on the Properties and Structure of the Surfaced Metal from 12cR18nI10tI steel
}

\author{
Sergey Dmitrievich Neulybin ${ }^{1}$, Yury Dmitrievich Schitsyn ${ }^{2}$, Dmitriy Sergeevich Belinin ${ }^{2}$, \\ Gleb L'vovich Permyakov ${ }^{2}$ \\ ${ }^{1}$ Institute of Continuous Media Mechanics of the Ural Branch of Russian Academy of Science, Russia \\ ${ }^{2}$ Perm National Research Polytechnic University, Russia
}

\begin{abstract}
Additive technologies (AT), or layered synthesis technologies, are one of the most dynamically developing areas of "digital" production. A common problem of additive technologies is to ensure the proper microstructure of the synthesized material and the elimination of defects. The use of filler wire as a working material allows you to get rid of the problems associated with the low productivity of existing methods, the high cost of equipment used, and the limited types of materials used, due to the use of powder systems. Products made of stainless chromium-nickel steels are widely used in various industries. The main problem with additive technologies is to ensure the properties of laminates not lower than those obtained by traditional methods. Characteristic defects of laminated materials obtained by surfacing are increased porosity, non-metallic inclusions, a decrease in ductility, and for high-alloy steels, a loss of special properties. This predetermined the development of research in the field of additional technological measures to improve the final properties of the product. Widely known methods based on the deformation effect on the surfacing zone. This paper presents the results of a study of the effect of ultrasonic vibrations on the structure and properties of the deposited steel 12Cr18Ni10Ti. The welding of wire grade 12Cr18Ni10Ti was carried out by arc welding with a non-consumable electrode in a protective argon gas medium. It was found that ultrasonic influence has an effect on the final grain size, structure formation and hardness, as well as on the geometry of the deposited layer. Studies show that the use of ultrasonic vibrations in the process of surfacing can be applied in the design of equipment for the implementation of processes of additive production.
\end{abstract}

Key words: Additive technologies, surfacing, strain hardening, ultrasonic action, high-alloy steel, grain score, microstructure, metallographic studies, microhardness, heat-affected zone.

\section{INTRODUCTION}

Developing and application of new energy and resource saving technologies for processing materials and parts manufacturing is one of development ways in modern engineering that is aimed at improving reliability and durability of manufactured products.[1] Recently, additive technologies have become common but their widespread introduction into production is discouraged by insufficient information about the effect of layer-by-layer metal surfacing on properties of finished products and the lack of technological recommendations for producing defect-free structure and required mechanical properties. This predetermined the need to search for technological methods that provide necessary properties of products metal during additive manufacturing [2-3].

Obtaining fine-grained structure of surfaced metal allows, as practice shows, to provide high mechanical properties of welded joint, as well as to increase technological strength, corrosion resistance and other special properties, increasing service life of the product as a whole [4-6]. Application of various impacts on the molten pool during surfacing is one of possible modification mechanisms of the deposited metal [7].

The existing specifics of cast metal crystallization during welding and surfacing allow us to establish harmonic frequency of metal solidification [8]. Some researchers believe that the main reason for cyclicity of crystallization is the release of melting latent heat that inhibits the advance of solidification front, others consider concentration overcooling before the interface boundary and yet others consider periodic heat supply to the boundary to be the reason. However, there is still no consensus [9-12].

Currently, there is a number of technological methods enabling influence on crystallization of metal during welding and surfacing in order to obtain a crushed structure [13, 14]. For these purposes we use: vibration of the welded product, energy input from a pulsed heat source, pulsed filler wire in different spatial positions, sources with modulation of welding current acting on liquid metal of the tail section of the pool, as well as, in some cases, input of separate heat sources influencing heat-affected zone near the seam axial line, 
external electromagnetic effects on the melt, both in continuous and pulsating mode with different frequencies of the magnetic field, etc. [15]

Some authors attributed conditions for weld metal structure formation to heat supply effect on solidification front. Other researchers believed that vibrations of molten metal of the welding pool have a significant role in structure formation [16-18].

\section{RESEARCH METHODOLGY}

For manufacturing critical structures steel grade $12 \mathrm{Cr} 18 \mathrm{Ni} 10 \mathrm{Ti}$ is used the most often among high-alloy steels. This can be explained by the fact that austenitic chromium-nickel steels such as 12X18H10T steel have high ductility and toughness, high mechanical properties at low temperatures, resistance against oxidation in air and in atmosphere of fuel combustion products at temperatures below $900 \mathrm{C}$ and good weldability. However, with a unique complex of physical and mechanical properties the steel under consideration has several disadvantages: relatively low strength and hardness, susceptibility of inter crystalline corrosion of the welds [19].

This paper proposes a method for quality improving of deposited layers of steel $12 \mathrm{Cr} 18 \mathrm{Ni10Ti}$ with layer-by-layer argon-arc surfacing during additive manufacturing of parts. To study possibilities of structure modifying we used ultrasonic action on deposited material using a waveguide connected to the lower surface of the plate.

Argon-arc surfacing was made on plates of $12 \mathrm{Cr} 18 \mathrm{Ni} 10 \mathrm{Ti}$ steel with a thickness of $3 \mathrm{~mm}$ on an installation with an inverter power source. Argon arc welding was performed according to the mode given in table 1. Waveguide is connected to the lower surface of the plate.

Table 1: Argon-arc surfacing mode

\begin{tabular}{|c|c|c|c|c|}
\hline $\begin{array}{c}\text { Surfacing } \\
\text { current, A }\end{array}$ & $\begin{array}{c}\text { Argon } \\
\text { consumpti } \\
\text { on, } \\
1 / \mathrm{min}\end{array}$ & $\begin{array}{c}\text { Feed rate, } \\
\mathrm{mm} / \mathrm{min}\end{array}$ & $\begin{array}{c}\text { Ultrasonic } \\
\text { action } \\
\text { frequency, } \\
\mathrm{kHz}\end{array}$ & $\begin{array}{c}\text { Distance } \\
\text { from } \\
\text { sample to } \\
\text { welding } \\
\text { torch } \\
\text { nozzle } \\
\text { section h, } \\
\mathrm{mm}\end{array}$ \\
\hline 120 & 7 & 200 & 22 & 10 \\
\hline
\end{tabular}

Authors of the study established [20] that ultrasonic action has the most favorable effect at $30 \mathrm{~mm}$ distance from the waveguide - position 3 (Figure 1). To assess ultrasonic effectthe samples were surfaced in the same mode without ultrasonic action (sample No1) and with it (sample No2).

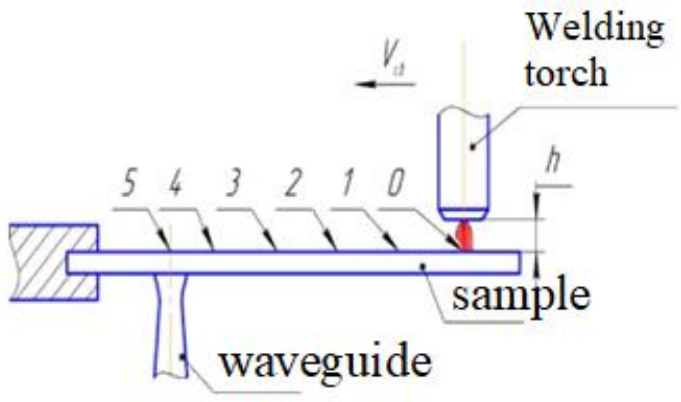

Figure 1: Surfacing scheme

\section{RESULTS AND ITS CONSIDTERATION}

Studying samples macrostructure showed that there are no defects (cracks, pores, non-fusion, etc.) on the macro sections of surfaced metal and heat-affected zone (HAZ). Macrostructure of surfacing metal in both cases is trans crystalline. The type of surfacing metal and HAZ formation is shown in Figures 1, 2. Results of measurement of parameters of surfacing welds are shown in Table 2.

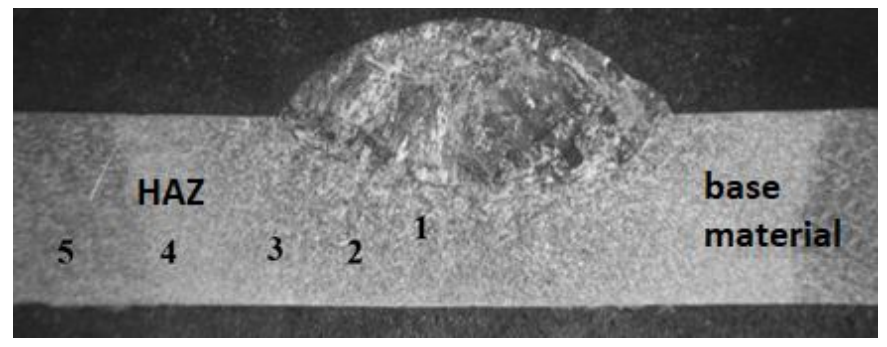

Figure 1: Surfacing metal and HAZ formation type on macro sections of studied samples without ultrasonic action

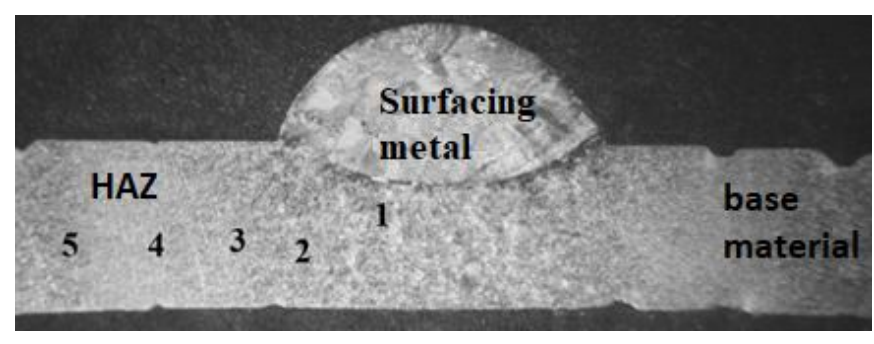

Figure 2: Surfacing metal and HAZ formation type on macro sections of studied samples with ultrasonic action

Table 2: Results of measurement of parameters of surfacing welds of studied samples

\begin{tabular}{|c|c|c|c|c|}
\hline \multirow[b]{2}{*}{$\begin{array}{c}\text { No } \\
\text { sample }\end{array}$} & \multicolumn{3}{|c|}{ Surfacing weld parameters, $\mathrm{mm}$} & \multirow{2}{*}{$\begin{array}{c}\text { HAZ } \\
\text { width, } \\
\text { mm }\end{array}$} \\
\hline & $\begin{array}{l}\text { Weld } \\
\text { width }\end{array}$ & $\begin{array}{c}\text { Weld } \\
\text { reinforcement }\end{array}$ & $\begin{array}{c}\text { Weld } \\
\text { penetration }\end{array}$ & \\
\hline 1 & 5,6 & 2,1 & 0,7 & 3,3 \\
\hline 2 & 6,1 & 1,5 & 1,0 & 2,5 \\
\hline
\end{tabular}


Studying samples microstructure showed the following:

During surfacing without ultrasonic action, the microstructure of surfaced metal is heterogeneous, with $\delta$-ferrite deposition (mainly in the direction of crystallite growth, Figure 3). Inside the crystallites there is austenite-ferritic microstructure that has a basket weaving form - clusters of rack-type grains with different direction of the racks (Figure 3). In the interlayer areas there are clusters of grains with a geometry different from the rack oneseparate small grains with a structure close to equiaxial, and larger grains of irregular geometric shape (Figure 3). At the fusion boundary in surfacing metal there is a light, slightly etching zone with a width of up to $\sim 0.25 \mathrm{~mm}$. The microstructure in this zone is coarse-grained, with an intragrain needle-like structure (Figure 4).
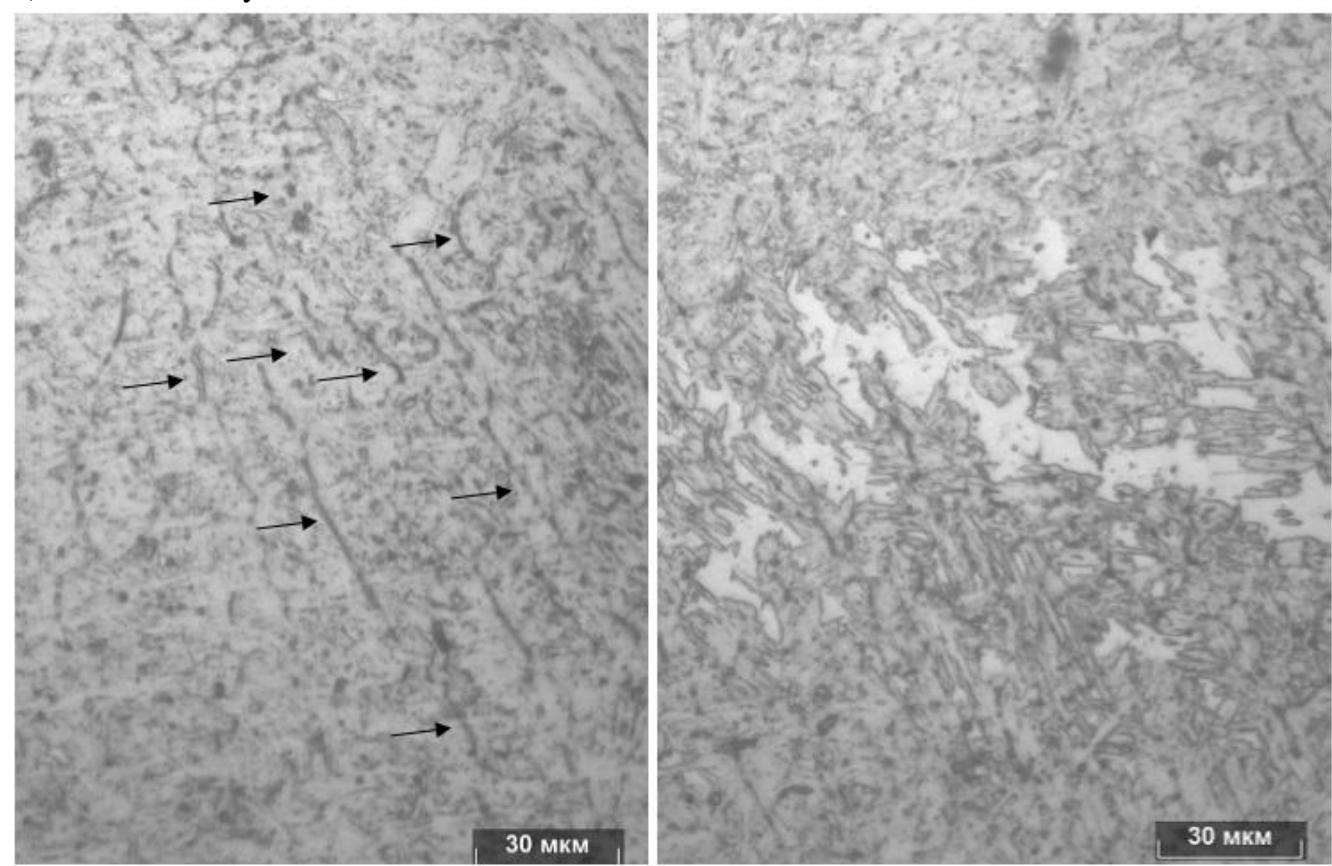

Figure 3: Microstructure of surfacing metal of sample No .1 x 500. Arrows indicate $\delta$-ferrite

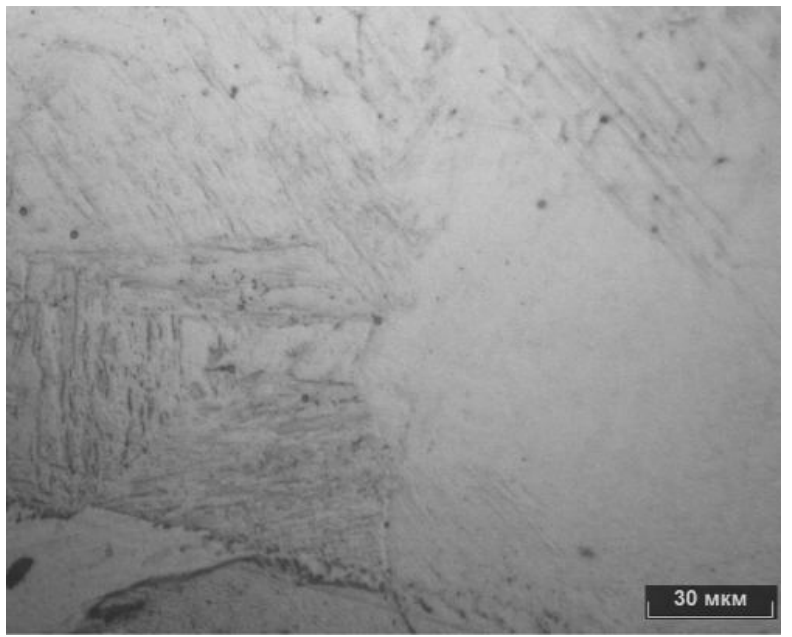

Microstructure of base material has traces of plastic deformation (the grain is slightly elongated in the direction of rolling), the grain size corresponds to 8 points (Figure 5). Grain growth is observed in the thermal influence zone at the fusion boundary with surfacing metal. There is band with a ferritic structure approximately of the grain size observed directly at the fusion boundary - Figure 5. Next, there is a ferrite-bainite structure where ferrite was separated along the grain boundaries and along the grain body with a needle-shaped formation according to Widmanstätten structure type. Further, as the grain is moved away from the fusion boundary, it becomes equiaxial; there is a grain refinement (up to 9-10 points) with the formation of a ferritic-pearlitic structure.

Figure 4: Microstructure view of surfacing metal of sampleNo1 at fusion boundary x 500 

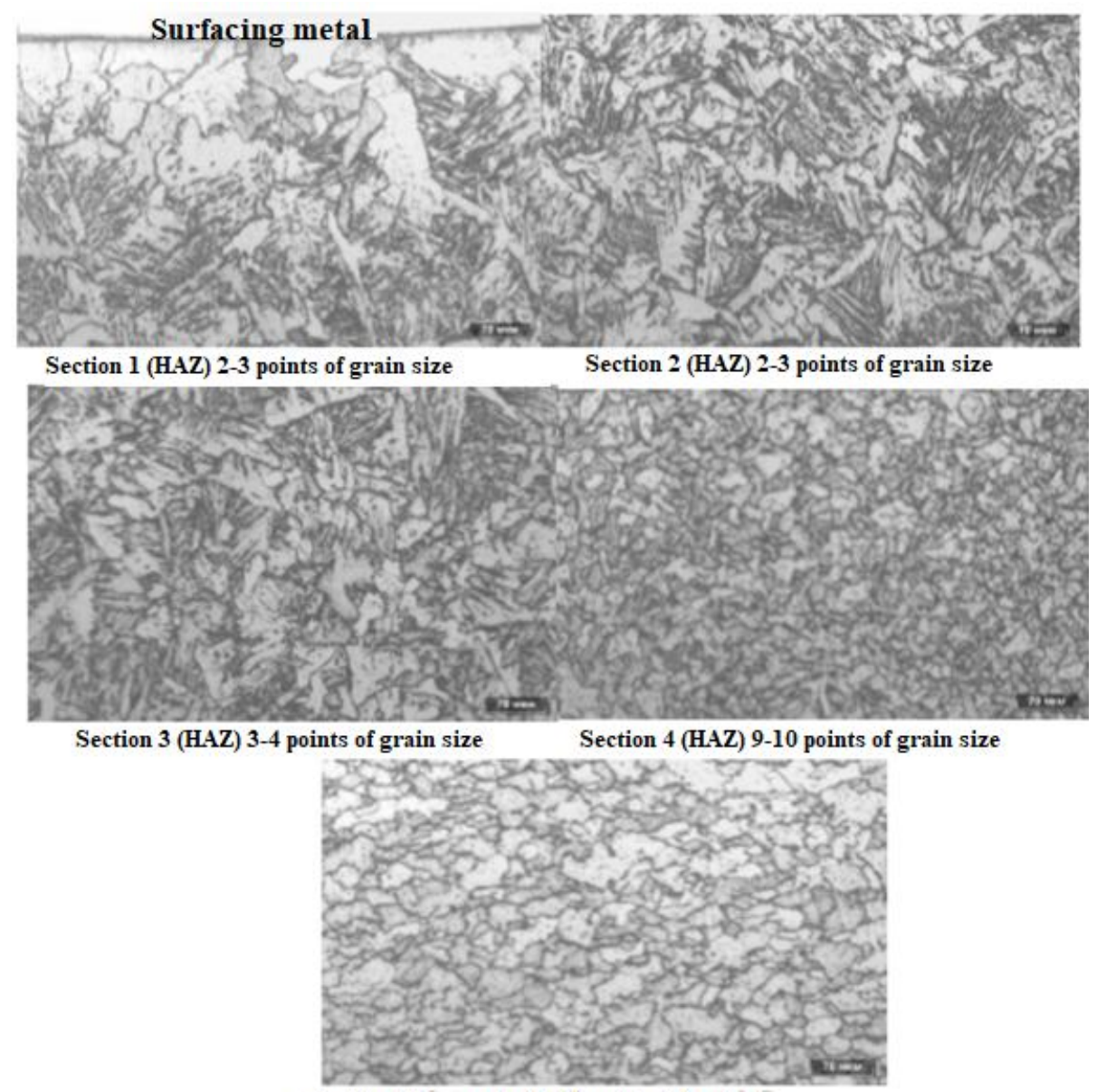

Section 5 (base material) 8 points of grain size

Figure 5: Microstructure of heat-affected zone and base material of sample No1 x 200

During surfacing with ultrasonic action, the microstructure of surfacing metal is heterogeneous, presumably austenitic-ferritic with carbide phase deposition that has a basket weaving structure - clusters of rack-type grains with different direction of the racks (Figure 6). Grain growth is less apparent in heat-affected zone at the fusion boundary (maximum 5 points), there is no solid ferritic structure bar (Figure 7). The nature of structure change in heat-affected zone is generally similar to sample No1 with differences in the size of heat-affected zone and grain size in characteristic HAZ zones (Figure 8).
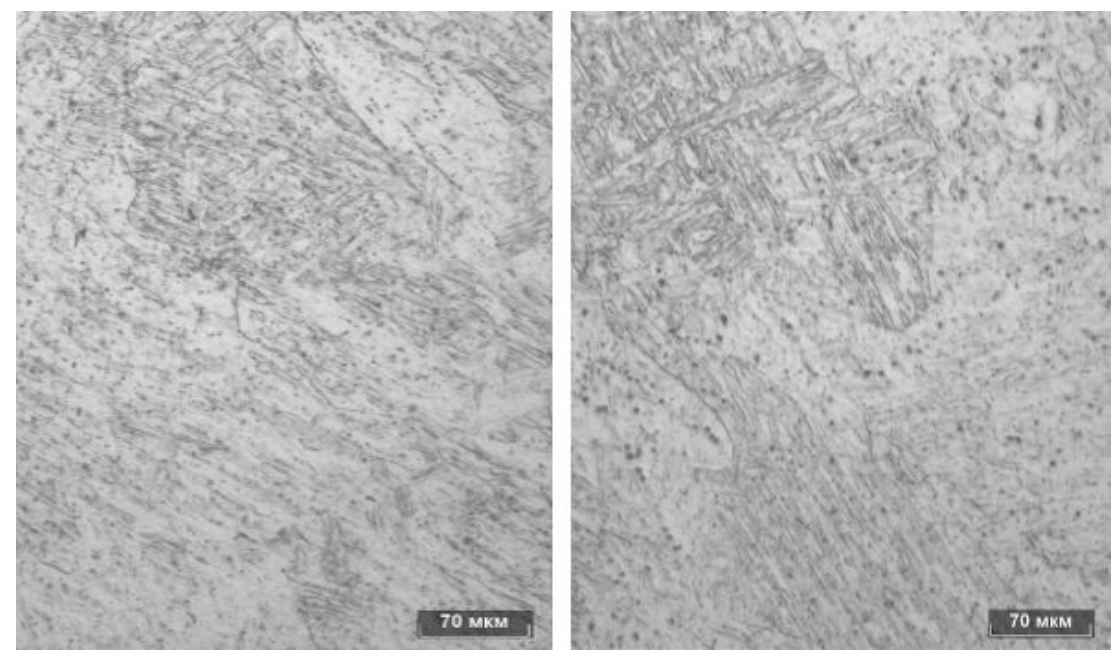

Figure 6: Microstructure of surfacing metal of sample No 2. x 500 


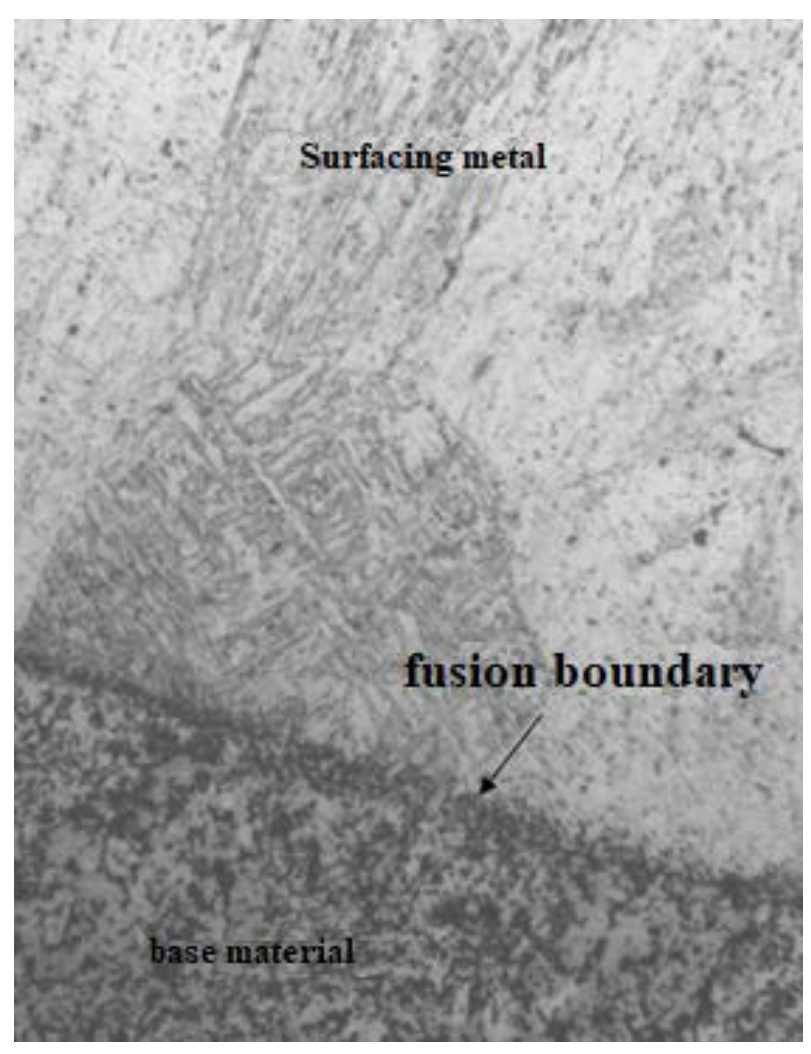

Figure 7: Microstructure view of surfacing metal of sample No2 at fusion boundary x 500

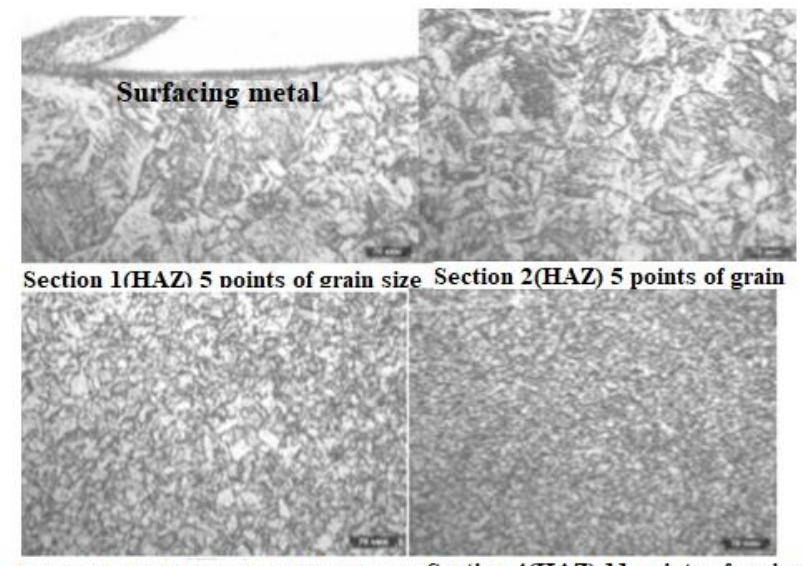

Section 3 (HAZ) 9 points of grain size Section 4 (HAZ) 11 points of grain size

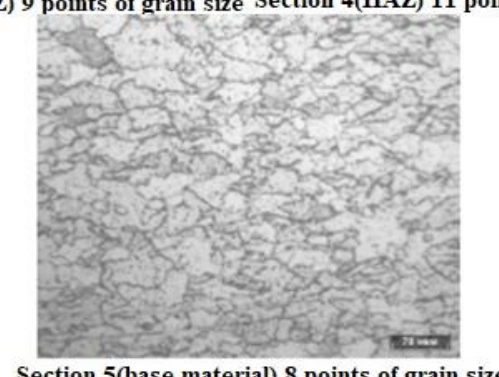

Figure 8: Microstructure of heat-affected zone and base material of sampleNo 5. x 200

During measurement of microhardness of surfaced layer, it was assumed that grain size refinement can lead to an increase of microhardness values in a sample produced with an ultrasonic action. The results are presented in Table 3.
Table 3: Results of microhardness measurement

\begin{tabular}{|c|c|}
\hline $\begin{array}{c}\text { Microhardness measurement } \\
\text { point }\end{array}$ & $\begin{array}{c}\text { Microhardness, } \mathbf{H V}_{\mathbf{\mu 5 0}}, \\
\mathbf{k g s} / \mathbf{m m}^{\mathbf{2}}\end{array}$ \\
\hline Sample 1 (surfaced material) & $268 \ldots 290$ \\
\hline Sample 2 (surfaced material) & $305 \ldots 338$ \\
\hline Base material & $118 \ldots 137$ \\
\hline
\end{tabular}

\section{CONCLUSION}

1. Ultrasonic vibrations effect on the structure and properties of surfaced metal applied in argon-arc surfacing process with $12 \mathrm{Cr} 18 \mathrm{Ni10Ti}$ steel is considered.

2. It is shown that ultrasonic vibrations have favorable effect on structure formation in surfaced metal, as well as in HAZ. It is established that grain size is reduced by $2-3$ points with ultrasonic action.

3. There is an increase of hardness of surfaced layer using ultrasonic vibrations up to $10 \%$ in relation to the processing modes without additional action.

4. Results of this study can be applied in development of technologies for additive manufacturing of critical products from high-alloy steels.

\section{ACKNOWLEDGEMENT}

The reported study was funded by RFBR, project number No 19-38-60043 $\backslash 19$, and The work was carried out with the financial support of the Ministry of Education and Science of the Russian Federation FSNM-2020-0028.

\section{REFERENCES}

1. W. E. Frazier. Metal Additive Manufacturing: A Review, Journal of Materials Engineering and Performance, Vol. 23, No 6, pp. 1917-1928, 2014. DOI: https://doi.org/10.1007/s11665-014-0958-z

2. N. I. Kakhovskii. Svarka nerzhaveiushchikh stalei. Tekhnika, Kiev, 1968, 312 p.

3. P. Adam. Svarka vysokolegirovannykh splavov dlia gazovykh turbin. In the book "Zharoprochnye splavy dlia gazovykh turbin" (Editor: R. E. Shalin), Metallurgiia, Moscow. pp. 388-408, 1981.

4. G. V. Sutyrin. Issledovanie mekhanizma vozdeistviia nizkochastotnoi vibratsii na kristallizatsiiu svarochnoi vanny, Avtomaticheskaia svarka, Vol. 5, pp. 7-9, 1975.

5. S. V. Aristov and V. L. Russo. Kristallizatsiia metalla shva pri nizkochastotnykh kolebaniiakh rasplava. Svarochnoe proizvodstvo, No 11, pp. 42-44, 1982.

6. S. W. Williams, F. Martina, A. C. Addison, J. Ding, G. Pardal and P. Colegrove. Wire + arc additive manufacturing, Mater. Sci. Technol., Vol. 32, pp. 641-647, 2016. http://dx.doi.org/10.1179/1743284715Y.0000000073

7. D. Ding, Z. Pan, D. Cuiuri and H. Li. Wire-feed additive manufacturing of metal components: technologies, developments and future interests, Int. J. Adv. Manuf. Technol., Vol. 81, pp. 465-481, 2015. http://dx.doi.org/10.1007/s00170-015-7077-3 
8. A. V. Petrov and U. I. Birman. Kristallizatsiia metalla shva pri impul'sno-dugovoi svarke, Svarochnoe proizvodstvo, Vol. 6, pp. 1-3, 1968.

9. P. A. Colegrove, J. Donoghue, F. Martina, J. Gu, P. Prangnell and J. Hönnige. Application of bulk deformation methods for microstructural and material property improvement and residual stress and distortion control in additively manufactured components, Scr. Mater., Vol. 135, pp. 111-118, 2017. http://dx.doi.org/10.1016/j

10. J. R. Hönnige, S. Williams, M. J. Roy, P. Colegrove and S. Ganguly. Residual stress characterization and control in the additive manufacture of large scale metal structures, 10th Int Conf. Residual Stress, Sydney, 2016.

11. R. G. Rizvanov, A. M. Fairushin, A. L. Karpov and M. Z. Zaripov. Issledovanie vliianiia vibroobrabotki v protsesse svarki na svoistva svarnykh soedinenii neftegazovogo oborudovaniia iz stali 09G2S, Neftegazovoe delo, Vol. 5, pp. 183-186, 2007.

12. Y. Xie, H. Zhang and F. Zhou. Improvement in geometrical accuracy and mechanical property for arc-based additive manufacturing using metamorphic rolling mechanism, J. Manuf. Sci. Eng., Vol. 138, No 11, pp. 1-8, 2015. http://dx.doi.org/10.1115/1.4032079

13. J. W. Elmer, S. M. Allen and T. W. Eagar. Microstructural Development during Solidification of Stainless Steel Alloys, Met Trans., Vol. 20A, pp. 21172131, 1989.

14. Allan G., Castability solidification mode and residual ferrite distribution in highly alloyed stainless steels. Technical Steel Research: European Commission, EUR 13941-Steelmaking, 1997, p. 85

15. J. Donoghue, A. A. Antonysamy, F. Martina, P. A. Colegrove, S. W. Williams and P. B. Prangnell, The effectiveness of combining rolling deformation with wire-arc additive manufacture on $\beta$-grain refinement and texture modification in Ti-6Al-4V, Mater. Charact., Vol. 114, pp. 103-114, 2016. http://dx.doi.org/10.1016/j.matchar.2016.02.001.

16. Y. Zhang, A. Bernard, R. Harik and K. P. Karunakaran. Build Orientation Optimization for Multi-Part Production in Additive Manufacturing, Journal of Intelligent Manufacturing, Vol. 5, pp. 34-48, 2015.

17. S. Kapil, F. Legesse, P. Kulkarni, P. Joshi, A. Desai and K. P. Karunakaran. Hybrid Layered Manufacturing using Tungsten Inert Gas Cladding, Progress in Additive Manufacturing, Vol. 1 No 1, pp. 79-91, 2016.

18. O. N. Nekhoroshkov. Vliianie ul'trazvukovoi obrabotki na strukturu, svoistva i razrushenie kompozitsii, obrazu iushchikhsia pri nanesenii pokrytii i svarke. Avtoreferat dissertatsii kand. tekhn. nauk. Institute of Strength Physics and Materials Science SB RAS, Tomsk, pp. 6-8, 2006.

19. A. A. Alov and V. S. Vinogradov. Povyshenie kachestva metalla svarnykh shvov, Svarochnoe proizvodstvo, Vol. 7, pp. 9-10, 1957.
20. E. A. Krivonosova, Iu. D. Shchitsyn, D. N. Trushnikov, S. N. Akulova, A. V. Myshkina, S. D. Neulybin and A. Iu. Dushina. Razrabotka tekhnologii posloinogo vyrashchivaniia zagotovki iz vysokolegirovannoi stali metodom plazmennoi naplavki, Metallurg, Vol. 2, pp. 70-77, 2019. 